http://dx.doi.org/10.15762/ZH.2015.32

JANUSZ MAŁŁEK

(Uniwersytet Mikołaja Kopernika w Toruniu)

\title{
RELACJA JANA FUNCKA Z SYNODU W KOŹMINKU W ROKU 1555 (PRZYCZYNEK DO KONTAKTÓW PROTESTANTÓW Z PRUS KSIĄŻĘCYCH, POLSKI I CZECH)
}

Słowa kluczowe: książę Albrecht Hohenzollern, Prusy Książęce, bracia czescy, protestantyzm, unia w Koźminku, synody protestanckie

W 1525 r. Prusy Książęce, księstwo będące lennem Polski, dały początek pierwszemu luterańskiemu Kościołowi w Europie. Wzajemne relacje wyznaniowe między protestanckim Księstwem Pruskim a katolicką Polską były niezwykle ważne dla obydwu stron. Objęcie rządów w Polsce w roku 1548 przez religijnie tolerancyjnego władcę, jakim był Zygmunt August, otwierało nowe możliwości zarówno dla rodzącego się polskiego ruchu reformacyjnego, jak i protestanckich kręgów w Prusach Książęcych. Na wagę tej problematyki badawczej wskazywał już w roku 1934 w swoim studium Wiktor Weintraub¹. Kolejną próbę przedstawienia tego zagadnienia podjął w 1983 r. Janusz Małłek². Celem publikowanego przyczynku jest poszerzenie informacji o wzajemnych kontaktach między protestantami polskimi i pruskimi w brzemiennym dla polskiego ewangelicyzmu roku 1555. Synod w Koźminku odbyty w dniach od 24 VIII do 2 IX 1555 r. znany jest w historiografii jako moment zawiązania unii między protestantami polskimi a braćmi czeskimi. Przebieg tego synodu jest nam znany dzięki publikacji protokołu $\mathrm{z}$ tych obrad $\mathrm{w}$ tomie I Akt synodów różnowierczych w opracowaniu Marii Sipayłło ${ }^{3}$. Z kolei w archiwum królewieckim (dzisiaj w Berlinie) w dziale Herzogliches Briefarchiv ${ }^{4}$

\footnotetext{
${ }^{1}$ Wiktor Weintraub, Udział Prus Ksiązęcych $w$ reformacji polskiej - przeglad badań, Reformacja w Polsce, t. 6: 1934, s. 38-63.

2 Janusz MaŁŁeK, Prusy Książęce a reformacja w Polsce, Komunikaty Mazursko-Warmińskie, 1983, nr 1, s. 9-17 (ponowny druk w: idem, Reformacja i protestantyzm w Polsce i $w$ Prusach (XVI-XX w.) (Opera selecta, vol. 4), Toruń 2012, s. 259-272).

${ }^{3}$ Akta synodów różnowierczych w Polsce (dalej cyt. ASRP), t. 1: (1550-1559), opr. Maria SiPAYŁŁo, Warszawa 1966, s. 18-45. Z opuszczeniami źródło to opublikował wcześniej: Józef ŁukAszewicz, Dzieje kościołów wyznania helweckiego w dawnej Małej Polsce, Poznań 1853, s. 22-44.

${ }^{4}$ Geheimes Staatsarchiv Preussischer Kulturbesitz, Berlin-Dahlem, Historisches Staatsarchiv Königsberg, Herzogliches Briefarchiv J-2, Kaste 992.
} 
przechowywany jest list Jan Funcka ${ }^{5}$ do księcia Albrechta datowany 13 VIII 1555 r. z Królewca. Pismo to liczy 11 stron, z tego 3 strony to właściwy list oraz 8 stron sprawozdania z rozmów, jakie J. Funck przeprowadził w Koźminku (niedaleko Kalisza) ze starszymi braci czeskich oraz przywódcami protestantów polskich. List ten, jak i kilka innych, opublikował Theodor Wotschke ${ }^{6} \mathrm{w}$ artykule poświęconym sejmowi w Piotrkowie w 1552 r. i synodowi w Koźminku w 1555 r., zaznaczając tylko, że pochodzą ze zbiorów królewieckich, jednak bez podania sygnatur. W opracowaniach historycznych przebiegiem obrad synodu w Koźminku zajmowano się marginalnie. Wspominają o nim już Andrzej Węgierski w Libri Quattor Slavoniae Reformatae w 1652 r.7 i Stanisław Lubieniecki w Historia Reformationis Polonicae (Freistadii 1682) ${ }^{8}$. Z kolei w XIX w. nieco miejsca poświęcił mu Walerian Krasiński w syntezie dziejów reformacji w Polsce, napisanej pierwotnie w języku angielskim", która w roku 1904 ukazała się drukiem w przekładzie na język polski ${ }^{10}$. Najbardziej szczegółowo omówił ten synod Th. Wotschke ${ }^{11} \mathrm{w}$ swojej historii reformacji polskiej. W innych pracach traktujących o dziejach polskiej reformacji o synodzie unijnym w Koźminku zaledwie się wspomina ${ }^{12}$. W historiografii czeskiej to ważne wydarzenie w dziejach braci czeskich znalazło swoich badaczy. Na uwagę zasługuje tutaj dzieło Jaroslava Bidlo ${ }^{13}$. Z kolei udział w synodzie w Koźminku delegatów $\mathrm{z}$ Prus, co nas tu najbardziej interesuje, analizowano w opracowaniach. Pierwsze wzmianki na ten temat znajdujemy w Preussiche Kirchen-Historia Christopha Hart-

${ }^{5}$ Jan Funck (1518-1566), studiował na uniwersytecie w Wittenberdze, gdzie w 1539 r. otrzymał tytuł magistra. W roku 1546 przybył do Prus Książęcych, w kolejnym roku objął urząd kaznodziei w kościele staromiejskim Królewca, a w roku 1549 został kaznodzieją książęcym. Był gorącym zwolennikiem nauki reformatora Andrzeja Osiandra (1498-1552), co spowodowało jego konflikt z pastorami wyznającymi ortodoksyjny luteranizm. Zdobył sobie pełne zaufanie księcia Albrechta, który wyraźnie skłaniał się do osiandryzmu. Zob. Franz Karl Weder, Johannes Funck, [in:] Altpreußische Biographie, Bd. 1, hrsg. v. Christian Krollmann, Marburg an der Lahn 1974, s. 202.

${ }^{6}$ Theodor Wotschкe, Der Petrikauer Reichstag 1552 und die Synode zu Koschminek 1555, Archiv für Reformationsgeschichte, Jg. 11: 1914, H. 2, s. 87-96.

${ }^{7}$ Andrzej WęGIERski, Libri Quattor Slavoniae Reformate, prefatione instruxit Janusz TAzBIR, Warszawa 1973, s. 76.

${ }^{8}$ Stanisław Lubieniecki, Historia Reformacji polskiej, tłum. ks. Edmund Bursche, Rocznik Teologiczny, R. 4: 1939, s. 34-36; idem, History of Polish Reformation and Nine Related Documents, translated and interpreted by George Huntston Williams, Minneapolis 1995, s. 126, 476, przyp. 121.

${ }^{9}$ Walerian Krasiński, Historical Sketch of the Rise, Progress and Decline of the Reformation in Poland, vol. 1, London 1838, s. 234, 274.

${ }^{10}$ Idem, Zarys dziejów powstania i upadku reformacji w Polsce, t. 1, wyd. ks. Juliusz Bursche, Warszawa 1904, s. 150, 170.

${ }^{11}$ Theodor Wotschкe, Geschichte der Reformation in Polen, Leipzig 1911, s. 141-143.

${ }^{12}$ Janusz TazBIR, Świt i zmierzch polskiej reformacji, Warszawa 1956, s. 93; Jerzy KŁoczowsKi, Some Remarks on the Social and Religious History of 16th Century Poland, [in:] The Polish Renaissance in its European Context, ed. by Samuel Fiszman, Bloomington 1988, s. 98 n.; Wacław Urban, Epizod reformacyjny, Kraków 1988, s. 23; Ambroise Jobert, Od Lutra do Mohyły. Polska wobec kryzysu chrześcijaństwa 1517-1648, przeł. Elżbieta S̨̨Kowska, Warszawa 1994, s. 65; Jolanta DworzaczKowA, Reformacja i kontrreformacja w Wielkopolsce, Poznań 1995, s. 20 n.

${ }^{13}$ Jaroslav Bidlo, Jednota Bratská v prvním vyhanaství, t. 1: 1548-1561, Praha 1900, s. 125-131. 
knocha $^{14}$. W biografii J. Funcka pióra Carla Alfreda Hasego ${ }^{15}$ odnajdujemy tylko krótką informację o udziale kaznodziei księcia Albrechta pruskiego w synodzie w Koźminku. Z kolei Hermann Freytag ${ }^{16}$ w biografii Antoniego Bodensteina, pastora $\mathrm{w}$ Toruniu, dostarcza interesujące informacje o rozmowach, jakie prowadził wysłannik księcia Albrechta pruskiego na ten synod J. Funck z przełożonym braci czeskich Janem Černým-Nigranusem (około 1510-1565) ${ }^{17}$. Wreszcie wzmiankę o misji J. Funcka w Koźminku zamieścił w swojej obszernej monografii poświęconej osiandryzmowi w Prusach Książęcych Jörg Rainer Fligge ${ }^{18}$.

Zanim przedstawię treść relacji J. Funcka z jego pobytu na synodzie w Koźminku, należy odpowiedzieć na kilka pytań. Co legło u podstaw decyzji księcia Albrechta na wydelegowanie swojego wysłannika na ten synod? Dlaczego zdecydował się na osobę J. Funcka? Jaką rolę odegrał na tym synodzie J. Funck i pozostali uczestnicy synodu z Prus Książęcych? Uwagę księcia Albrechta zaprzątały wówczas dwie kwestie: 1) sytuacja konfesyjna w Polsce w związku z wyraźną tutaj erupcją ruchu reformacyjnego w latach pięćdziesiątych XVI w.; 2) zażegnanie sporów religijnych w jego księstwie.

Rzeczywiście w roku 1555 ruch reformacyjny w Polsce osiągnął punkt, który mógł zepchnąć Kościół katolicki z piedestału. Na sejmie w Piotrkowie w maju 1555 r. 113 posłów szlacheckich przedstawiło w języku polskim Wyznanie augsburskie z roku 1530 i zadeklarowało mu wierność, nawet gdyby to groziło utratą życia ${ }^{19}$. Ostatecznie sejm 1555 r. zakończył się tzw. Interim (tymczasem), czyli odroczeniem rozwiązania spraw wyznaniowych w Polsce przez sobór narodowy lub sobór powszechny ${ }^{20}$. Nie może więc dziwić to, że książę Albrecht i teolodzy z Księstwa Pruskiego pilnie śledzili i wspierali wysiłki protestantów polskich zmierzające do zjednoczenia różnych nurtów reformacyjnych, co też miało miejsce w Koźminku.

Niemniej ważne było wybadanie, jakie stanowisko zajmują bracia czescy (a pewna ich grupa zamieszkiwała od roku 1548, po wygnaniu ich z ojczyzny przez Ferdynanda I, w Prusach Książęcych, m.in. w Dąbrównie i Działdowie) w spo-

\footnotetext{
${ }^{14}$ Christoph Hartknoch, Preussische Kirchen-Historia, Frankfurt am Main 1686, s. 379-381.

${ }^{15}$ Carl August Hase, Herzog Albrecht von Preussen und sein Hofprediger, Leipzig 1879, 234-235.

${ }^{16}$ Hermann Freytag, Antonius Bodenstein. Ein Theologenleben aus dem Jahrhundert der Reformation, Zeitschrift des Westpreussischen Geschichtvereins, H. 65: 1925, s. 30 n.

${ }^{17}$ Jan Černý (1510-1565), w 1548 r. pojawił się w Prusach Królewskich, w Toruniu. W dniu 7 X 1548 r. wziął udział w Królewcu z 8 innymi teologami braci czeskich w przesłuchaniu przed komisją złożoną z teologów pruskich, m.in. także Jan Funcka, w sprawie zgodności ich nauki z Konfesją Augsburską i miejscowymi luterańskimi ustawami kościelnymi. Zob. Jerzy ŚLIZIŃski, $Z$ działalności literackiej Braci Czeskich w Polsce (XVI-XVII w.), Wrocław 1959, s. 31 n.

${ }_{18}$ Jörg Rainer Fligge, Herzog Albrecht von Preussen und der Osiandrismus 1522-1568, Bonn 1972, s. 279.

${ }^{19}$ J. MAŁŁEK, Reformacja i protestantyzm w Polsce i Prusach, s. 90-91, 96.

${ }^{20}$ Ibid., s. $48-50$.
} 
rze teologicznym związanym z nauką Andrzeja Osiandra (1498-1552). Naukę A. Osiandra w dużym uproszczeniu można ująć w dwóch punktach.

1. Nauka o usprawiedliwieniu.

W teologii chrześcijańskiej funkcjonuje pojęcie „usprawiedliwienie”. Oznacza uczynienie człowieka grzesznego sprawiedliwym w oczach Bożych, tak jakby w pełni wypełniał on obowiązujące go przykazania. Konsekwencją usprawiedliwienia jest zbawienie. Marcin Luter głosił, że wiara jest niezbędnym warunkiem, aby grzesznik został przez Boga usprawiedliwiony, choć na to nie zasługuje. Dobre uczynki chrześcijanina winny być motywowane wiarą w Boga, a nie formą zasłużenia sobie na Boską łaskę. A. Osiander podzielał pogląd M. Lutra, że wiara prowadzi do usprawiedliwienia przez Boga, lecz jest to warunek niewystarczający. „U podstaw sprawiedliwości leży - jego zdaniem - zamieszkanie w człowieku boskiej natury Chrystusa, a nie wiara w Jego odkupicielską śmierć na krzyżu”"21. A. Osiander uważał - pisze ks. Tadeusz Wojak ${ }^{22}$ - że jeśli orzeczenie o usprawiedliwieniu nie jest ściśle związane z przemianą człowieka, dzięki której staje się on sprawiedliwy, to Bóg byłby niesprawiedliwym sędzią. Wybaczenie grzechów i dzieło zbawienia wymaga sprawiedliwego i efektywnego osądzenia ${ }^{23}$. Poglądy te zbliżały A. Osiandra - zdaniem jego ówczesnych oponentów - do nauki katolickiej i wzbudziły ostry sprzeciw.

2. Nauka o naturze boskiej.

Andrzej Osiander rozdzielał dwie natury w Jezusie Chrystusie (boską i ludzką). Chrystus jest odblaskiem Boga, Chrystus jest naszą sprawiedliwością z powodu Bożej osobowości, a nie ludzkiej. Według M. Lutra nie można w Chrystusie oddzielać dwóch natur ${ }^{24}$.

Najlepiej sytuację religijną w Prusach Książęcych wywołaną tzw. sporem osiandrowskim przedstawił książę Albrecht w rozmowie odbytej w dniu 23 VII 1555 r. na zamku królewieckim ze starszymi braci czeskich przybyłymi zarówno z Moraw, jak i Księstwa Pruskiego. Treść tej rozmowy znamy dzięki relacji ${ }^{25}$, jaką spisał uczestnik tych rozmów Jan Lorenc ${ }^{26}$. Brzmi ona następująco: „Najpierwej tedy [ks. Albrecht] przełożył szeroko, jako w księstwie jego a zwłaszcza tu w mie-

\footnotetext{
${ }^{21}$ Religia. Encyklopedia PWN, t. 7, red. Tadeusz GadACz, Bogusław Milerssi, Warszawa 2003, s. 451-452; Die Luther-Lexikon, hrsg. v. Volker Leppin, Gury SCHNEIdER-LudorfF, Regensburg 2014, s 526; Paweł Janowski, Osiander Andreas, [in:] Encyklopedia katolicka, t. 14, Lublin 2010, s. 885.

${ }^{22}$ Ks. Tadeusz WoJak, Ustawy kościelne w Prusach Książęcych w XVI wieku, Warszawa 1993, s. 90-91.

${ }^{23}$ Ernst Bizer, Osiander Andreas, [in:] Die Religion in Geschichte und Gegenwart, Bd. 4, hrsg. v. Kurt Galling, Tübingen 1960, s. 1730-1731.

${ }^{24}$ Ludwig PeLt, Osiander Andreas, [in:] Real-Encyklopädie für protestantische Theologie und Kirche, hrsg. v. [Johann Jakob] Herzog, Bd. 10, Gotha 1858, s. 720-724.

${ }^{25}$ ASRP, t. 1, s. 321-335.

${ }^{26}$ Jan Lorenc (Třebičský) (zmarły w 1589 r.), występuje także jako Laurencjusz. Studiował w Wittenberdze, a od roku 1549 w Królewcu. Od roku 1568 był duchownym Jednoty w Ostrorogu. Zob. J. ŚLIZIŃsKI, op.cit., s. 52-53.
} 
ście Królewcu, w kolejii [czechizm - w kolegium, czyli na uniwersytecie - J.M.] między mistrzami, doktorami, teologami a kaznodziejami wielki spór się wszczął około artykułu o usprawiedliwieniu z wiary. Bo jedni społem z Osyjandrem dzierżą a uczą tę sprawiedliwość być Boga wszechmogącego w miłości, a w miłosierdziu i łasce Jego, Ojca, Syna i Ducha Świętego jedynego Pana Boga etc. A gdy ten Pan Bóg w człowieku przybywa a onym rucha, ku nowemu odrodzeniu przywodzi, a w nowy żywot odmienia, iż go tedy usprawiedliwia. A tu przywodzi wiele pism o przemieszkiwaniu Pana Krystusa w nas przez wiarę a o sprawie Ducha Św., a iż ta sprawiedliwość, o której drudzy mówią, tylko przywłaszczona, nic nie jest a próżna jest. Druga strona [przeciwnicy A. Osiandra - J.M.] o usprawiedliwieniu wierzy, uczy i każe, iż nasza sprawiedliwość jest Krystus Pan, z strony człowieczeństwa a z strony śmierci i skutków: a tak odpuszczenie grzechów dla Krystusa i Jego zasługi, a przywłaszczenie Jego doskonałości i za nas dopełnienie Zakonu, i Krystusowo nas zastępowanie przed Ojcem Niebieskim etc. Item, jak się sobie te obie strony nieprzystojnie sprzeciwiają, jedni drugie sromocą, bluźnią, uragają a przenagabywają, aż jm. książe kazania niespokojne im zakazać raczył”. I dalej: „A przetoż prosił jm. a żądał br[ata] Jana Starszego [Černýego - J.M.], aby o tych różnościach a odpornościach sąd swój, którzy by byli prawi, którzy krzywi, albo też oboi byli li w czym zdrożni, aby to jawnie a uprzejmie oznajmił a rozumienia brackiego przy tym artykułu żeby sumę powiedział, a radę dał, jako by sie jm. w tych niezgodach miał sprawować. Responsio, że sprawie jmks. wyrozumiano, a za co jmks. żąda, iż to są wielkie a niebezpieczne rzeczy: sądzić tak wielkie a znamienite spory, przetoż proszą, może-li bez tego być" ${ }^{27}$. Książę natychmiast zapewnił, że ich opinia, rozstrzygająca, która $\mathrm{z}$ dwóch stron sporu ma rację, lub nawet gdyby okazało się, że obydwie strony tkwią w błędzie, i ewentualna porada, jak winien postąpić w celu zażegnania tego konfliktu, nie niesie dla braci żadnego zagrożenia. Ta deklaracja mogła oznaczać, że ich opinię zachowa w tajemnicy. W tej sytuacji bracia obiecali ją wygotować i 29 VII 1555 r. przekazali ją osobiście księciu² ${ }^{28}$. W opinii Ch. Hartknocha jeszcze z roku 1686 niektóre fragmenty tego dokumentu nie odbiegają daleko w swojej treści od poglądów A. Osiandra ${ }^{29}$. Książę Albrecht przywiązywał wielką wagę do bytności braci czeskich na rozmowach w Królewcu, skoro wziął udział w ich nabożeństwie. J. Lorenc opisuje to tak: „Było kazano na Lekcyją św. Jana 6,51 «Jam jest chleb żywy, którym z nieba zstąpił etc.» Pan Wylem [Wilhelm Krzynecki ${ }^{30}$ - J.M.] po niemiecku wszystko wykładał a szeptał jm. książęcej, ano i przy posługiwaniu sprawę dawał, a on rad to wszystko słyszał a widział,

\footnotetext{
${ }^{27}$ ASRP, t. I, s. 324.

${ }^{28}$ Treść opinii w: ibid., s. 324-332.

${ }^{29}$ Ch. Hatknoch, op.cit. s. 379.

${ }^{30}$ Wilhelm Křinecký (Krzynecki), zmarły około 1568 r., baron z Ronowa, wygnany z Czech przez króla czeskiego Ferdynanda I z powodu nieprzyjęcia cesarskiego Interim z roku 1548. Gościny udzielił mu książę Albrecht pruski. Był starostą w Działdowie w latach 1555-1568, zob. ASRP, t. 1, s. 356 (indeks); Anton Gindely, Quellen zur Geschichte der Böhmischen Brüder, Wien 1859 (dalej cyt. QGBB), s. 20, 90, 106, 121-122.
} 
aż żałośnie płakał, a żądał, żeby mu to kazanie do łacińskiego języku przełożonym było a posłano, cóż się potem stało etc." ${ }^{31}$

Wracając do osoby J. Funcka, wysłannika księcia Albrechta na synod w Koźminku, to trzeba stwierdzić, że wybór ten był trafny zwłaszcza ze względu na jego wcześniejsze kontakty z braćmi czeskimi. J. Funck był tą osobą, która 6 VII 1548 r. w Morągu w imieniu księcia Albrechta wystawiła braciom czeskim dokument ${ }^{32}$ zezwalający na osiedlenie się w Księstwie Pruskim pod warunkiem dostosowania się w sprawach wyznaniowych do wymogów, jakie obowiązują w pruskim Kościele. Z kolei pod koniec grudnia 1548 r. J. Funck uczestniczył w przesłuchaniu braci czeskich $\mathrm{w}$ kwestii zgodności ich wyznania $\mathrm{z}$ wyznaniem luterańskim $\mathrm{w}$ Prusach Książęcych ${ }^{33}$. Ostatecznie książę Albrecht ogłosił w 1549 r. specjalny „Porządek kościelny" (Kirchenordnung) dla braci czeskich ${ }^{34}$. W synodzie w Koźminku z Prus Książęcych obok J. Funcka uczestniczyli: brat czeski Jan Gyrk ${ }^{35}$, luteranin Hieronim Malecki ${ }^{36} \mathrm{i}$ wspominany Wilhelm Křinecký (Krzynecki), starosta działdowski, także brat czeski. O przyjeździe J. Funcka na synod w Koźminku w protokole napisano: „Z nim [z Kř́ineckým - J.M.] też przyjechał Ioannes Funck, kaznodzieja książęcy, ut essent spectatores actionis" ${ }^{37}$. Rzeczywiście ich rola, zwłaszcza J. Funcka, sprowadzała się do pilnego obserwowania przebiegu obrad i prowadzenia rozmów zakulisowych. Spośród pozostałych uczestników synodu z Księstwa Pruskie-

\footnotetext{
${ }^{31}$ ASRP, t. 1, s. 334.

${ }^{32}$ QGBB, s. 88-89; Urkundenbuch zur Reformationsgeschichte des Herzogtum Preussen, hrsg. v. Paul Tschackert, Bd. 1-3, Leipzig 1890 (dalej cyt. UB), tu: Bd. 2, s. 190, nr 2120.

${ }^{33}$ QGBB, s. 92-97; UB, Bd. 1, s. 344; Bd. 3, s. 205, nr 2160. Według pierwszego źródła przesłuchanie to miało się odbyć 27 i 28 XII 1555 r., natomiast według drugiego źródła 24 grudnia tegoż roku. Podobnie nazwiska „egzaminatorów” różnią się w obydwu dokumentach. Według QGBB (s. 92, 95) egzaminatorami byli: rektor uniwersytetu w Królewcu mgr Phillipus oraz dr Michael, Peter, mgr Johann Zetel (proboszcz w Królewcu) i mgr Hieronim, a także mgr Fryderyk Staphylus i mgr Jan Funck. Z kolei według UB (Bd. 1, s. 344) egzaminatorami byli: dr Piotr Hegemon, dr Melchior Isinder, mgr Jan Doetsch, mgr Fryderyk Staphylus i mgr Jan Funck. Na pewno wymieniony w QGBB mgr Filip nie mógł być rektorem uniwersytetu w Królewcu w semestrze zimowym 1555 r., gdyż był nim medyk dr Johannes Placotomus (Bretschneider), zob. Georg ErLer, Die Matrikel und Promotionsverzeichnisse der Albertus-Universität zu Königsberg in Preussen, Bd. 1, Leipzg 1908, s. 9. Wspomniany rektor Filip miał pytać egzaminowanego Jerzego Israela w języku polskim (QGBB, s. 95), kiedy ten miał kłopoty z odpowiedzią w języku łacińskim. Raczej egzaminatorem tym był Staphylus, który rzeczywiście znał język polski. Zob. Ute Mennecke-Haustein, Conversio ad Ecclesiam. Der Weg des Fredrich Staphylus zurück zur vortridentinischen katholischen Kirche, Heidelberg 2003, s. 59.

${ }^{34}$ Walther Hubatsch, Geschichte der evangelischen Kirche Ostpreussen, Bd. 1, Göttingen 1968, s. 79; Bd. 3, Göttingen 1968, s. 12-20.

${ }^{35}$ Jan Gyrk (zmarły w 1605 r.), kaznodzieja braci czeskich w Nidzicy (Nibork), zob. ASPR, t. 1, s. $20,24,40,333$.

${ }^{36}$ Hieronim Malecki (urodzony około 1527 r. w Krakowie, zmarły w 1583/1584 r. w Ełku), pastor, nauczyciel i drukarz w Ełku. Zob. Henryk BArycz, Malecki Hieronim, [in:] Polski słownik biograficzny (dalej cyt. PSB), t. 19, Wrocław-Warszawa-Kraków-Gdańsk 1974, s. 295-297; Tadeusz Oracki, Stownik biograficzny Warmii, Prus Książęcych i Ziemi Malborskiej od połowy XV do końca XVIII wieku, t. 2, Olsztyn 1988, s. 29-30.

${ }^{37}$ ASRP, t. 1, s. 20.
} 
go aktywność w czasie obrad wykazywał Jan Gyrk ${ }^{38}$. Interesująca jest na synodzie obecność Hieronima Maleckiego, pastora na Mazurach. Niestety źródła milczą, jakie były przyczyny jego udziału w obradach.

Relacja J. Funcka z synodu w Koźminku składa się z listu do księcia Albrechta datowanego 13 IX 1555 r. z Królewca i dołączonego do niego sprawozdania zatytułowanego „Privatae commissiones Cossminici mihi iniunctae”. W liście J. Funck informował księcia, że szczęśliwie w poniedziałek (9 września) powrócił w umiarkowanym zdrowiu z podróży i dzięki Boskiej opiece uniknął niebezpieczeństw od złych ludzi. W podróży powrotnej nasłuchał się różnych „dziwnych” wypowiedzi, które po części z pewnością dotarły też do księcia. J. Funck w sposób zawoalowany wspomina tutaj o napiętej sytuacji w Księstwie Pruskim spowodowanej tzw. sporem osiandrowskim. Jako zwolennik A. Osiandra mógł się czuć zagrożony mimo opieki książęcej. W liście informował księcia, że kaznodzieje czescy i polscy doprowadzili do zjednoczenia ich wyznań. Polscy duchowni uznali i przyjęli za swoją naukę braci czeskich, a także zaakceptowali ich rozwiązania w zakresie dyscypliny kościelnej. Jedynie w zakresie liturgii chcą pozostać przy swojej tradycji. J. Funck informował dalej księcia, że unię wyznaniową z braćmi czeskimi w pełni zaakceptowali zebrani tu szlacheccy wyznawcy protestantyzmu zarówno z Małopolski, jak i Wielkopolski. Obiecał też księciu bardziej szczegółowo opisać przebieg synodu, ale tego nie uczynił. Zauważył to już Th. Wotschke ${ }^{39}$, publikując ten list. J. Funck informował również księcia, że do listu dołącza raport z rozmów, jakie przeprowadził zgodnie z instrukcją książęcą zarówno ze starszymi braci czeskich, jak i przedstawicielami protestanckiej szlachty polskiej. Wieczorem 30 VIII 1555 r. w Koźminku J. Funck w towarzystwie W. Křynickýego odbył dłuższą rozmową ze starszym braci czeskich J. Černým. Tematem rozmowy były poglądy religijne przeciwnika nauki A. Osiandra - Antoniego Bodensteina ${ }^{40}$, pastora w Ostródzie.

${ }^{38}$ Ibid., s. 24, 40.

${ }^{39}$ Th. Wotschke, Die Petrikauer Reichstag 1552, s. 88.

${ }^{40}$ Antoni Bodenstein (urodzony około 1517 r. w Wittenberdze, zmarły w 1572 r. w Malborku). Był bratankiem znanego reformatora dr. Andrzeja Bodensteina (Karlstadt). Immatrykulował się na uniwersytecie w Wittenberdze w roku 1530. Po uzyskaniu magisterium najpierw udał się na południe Niemiec, a potem na Morawy, gdzie zapoznał się z nauką braci czeskich. W 1543 r. objął urząd pastora w Kwidzynie. Z chwilą przybycia uciekinierów braci czeskich do Prus Książęcych w 1548 r. starał się pozyskać dla nich przychylność Pawła Speratusa, biskupa pomezańskiego. W latach 1553-1557 był pastorem w Ostródzie. W czasie tzw. sporu osiandrowskiego znalazł się w grupie pastorów ortodoksyjnych luteran zwalczających naukę Andrzeja Osiandra i jego stronników. Razem z innymi 12 pastorami podpisał uchwały synodu w Ostródzie w 1553 r., potępiające naukę Osiandra o usprawiedliwieniu. Z kolei znalazł się wśród 22 pastorów na synodzie w Zalewie w końcu roku 1554, którzy domagali się pozostawienia dawnego „Porządku kościelnego” (Kirchenordnung) z lat 1525, 1544 i niewprowadzania fałszywej nauki A. Osiandra. Nadmierne zaangażowanie się A. Bodensteina w ten spór spowodowało, że musiał opuścić księstwo. Osiadł w 1557 r. na krótko w Toruniu, aby w 1558 r. wrócić do Prus Książęcych na urząd pastora w Kwidzynie. Zob. Paul ARndT, Anton Bodenstein, [in:] Altpreußische Biographie, Bd. 1, s. 65; H. FreYtAG, op.cit., s. 15-34. 
Wydawałoby się dziwne, że sprawa pojedynczego pastora w Księstwie Pruskim znalazła priorytet w sprawozdaniu J. Funcka dla księcia Albrechta. Ma to jednak swoje uzasadnienie. Książę Albrecht na synodzie w Królewcu latem 1554 r. pragnął doprowadzić do kompromisu między ortodoksyjnymi luteranami i osiandrystami. Napotkał wszak na zdecydowany opór tych pierwszych. Dnia 19 IX 1554 r. 97 księży - wśród nich A. Bodenstein - podpisało protest ${ }^{41}$ adresowany do księcia Albrechta. Pisali, że konfesja nie może być przedmiotem dyskusji ani kompromisu. Właściwą drogą jest egzekucja dawnego stanu Kościoła, co książę przecież obiecał. Byli zdecydowani opuścić obrady synodu, gdyż dalsze rokowania nie miały według nich sensu. Książę urażony tą formą nacisku zamknął synod 24 IX 1555 r. ${ }^{42}$ Trzy dni później drukiem ukazał się mandat książęcy (Synodalabschied), w którym nakazywano przerwanie wszelkich dyskusji w sprawach religijnych i zachowanie spokoju w kraju. W razie niepodporządkowania się grożono konsekwencjami. Skutek był odwrotny. Dyskusje pastorów w mniejszych gremiach trwały nadal. Szczególną aktywnością odznaczali się na tym polu pastorzy: Franciszek Marshausen z Sępopola, Franciszek Burchardi z Prabut, Jan Cracovita z Pasłęka i A. Bodenstein z Ostródy ${ }^{43}$. Już 31 I 1555 r. został zwolniony z urzędu pastorskiego J. Cracovita ${ }^{44}$. Podobne konsekwencje groziły pozostałym. Tymczasem 11 VIII 1555 r. książę ogłosił kolejny mandat ${ }^{45}$, w którym zakazywał poddanym rozprawiania na temat nauki o usprawiedliwieniu. Ogłaszał amnestię dla obydwu stron sporu. Mandat $\mathrm{w}$ formie plakatu miał być ogłoszony $\mathrm{z}$ kazalnic i przybity do bram kościelnych. Oporni mieli się liczyć z wydaleniem z księstwa. Tak też się stało. W ciągu roku 1555 pozostali trzej z wymienionych księży musieli opuścić Prusy Książęce. F. Marshausen znalazł zatrudnienie w parafii w Niemczech, w Hildesheim, a F. Burchardi w Gdańsku ${ }^{46}$. Natomiast - jak wynika z rozmów J. Funcka z J. Čzerným w Koźminku - los A. Bodensteina nie był rozstrzygnięty. J. Funck prosił swego rozmówcę o wyjaśnienie, jak bracia czescy nauczają w kwestii sakramentu komunii świętej, gdyż pojawiły się wątpliwości, które rozniecił A. Bodenstein. Jak pisał J. Funck, był on świadkiem ich nabożeństwa sprawowanego z komunią świętą i to mu w zupełności wystarczyło, ale księciu musiał przedstawić ich wyraźne stanowisko. Według J. Funcka A. Bodenstein tkwił w błędzie i szukał oparcia u braci czeskich, twierdząc, że jego poglądy w sprawie dogmatów religijnych są zbieżne z tym, co oni głoszą. Książę był gotów puścić w niepamięć „słabości” A. Bodensteina, ale jeśli nadal będzie w nich trwać, będzie zmuszony go ukarać. J. Funck pisał, że będzie wdzięczny, jeśli pouczą A. Bodensteina, by nie trwał w błędzie. J. Černý zaniepokoił się tymi podejrzeniami, bo widział w nich niebezpieczeństwo dla swoich wyznawców w Księstwie Pruskim. W odpowiedzi

\footnotetext{
${ }^{41}$ J.R. FLIGGE, op.cit., s. 249.

${ }^{42}$ Ibid., s. 251.

${ }^{43}$ H. Freytag, op.cit., s. 28.

${ }^{44}$ Ibid., s. 28 , przyp. 3.

${ }^{45}$ J.R. FligGE, op.cit., s. 280.

${ }^{46}$ Ibid., s. 283.
} 
stwierdził, że jest poruszony wątpliwościami co do prawowierności ich konfesji. Deklarował, że w komunii świętej wierni otrzymują prawdziwe ciało i krew Chrystusa. Boska i ludzka natura tworzą jedność w Chrystusie. Jednostka ludzka ma swój udział w naturze Boskiej Chrystusa. Dodajmy, że stwierdzenie to byłoby bliskie nauce A. Osiandra „o zamieszkaniu w człowieku Boskiej natury Chrystusa”. J. Černý, broniąc się, twierdził, że A. Bodenstein opacznie zinterpretował ich doktrynę zawartą w księdze ich Kościoła - Apologii. Dalej mówił, że A. Bodenstein nie jest członkiem ich wspólnoty. Ma kontakty z braćmi, gdyż swego czasu był na Morawach nauczycielem dzieci jednego z ich współwyznawców. Rzeczywiście zgłosił taki akces za pośrednictwem Jana Gyrkego, pastora braci czeskich w Nidzicy. Bracia czescy są jednak ostrożni w przyjmowaniu nowych wiernych. J. Černý prosił, aby książę wstrzymał się z radykalnymi krokami wobec A. Bodensteina do czasu, aż on się z nim rozmówi. O wyniku tej rozmowy spiesznie powiadomi księcia listownie lub za pośrednictwem W. Křynickýego albo J. Funcka.

W swoim raporcie dla księcia Albrechta J. Funck poruszył kolejną kwestię. Był obecny na wieczornym kazaniu i zastanowiła go jego treść. Osoby obecne na tym kazaniu były jego tłumaczami. W pełni podzielały poglądy kaznodziei. Treść kazania sprowadzała się do tezy, że władza świecka nie może zarządzać Kościołem, bo to jest domeną duchowieństwa. W świetle wygnania braci czeskich z Moraw $\mathrm{w}$ związku z ich niepodporządkowaniem się dekretowi cesarskiemu o Interim $\mathrm{z}$ roku $1548^{47}$ taka wykładnia wzajemnych relacji między władzą świecką a duchowną zawarta w tym kazaniu była w pełni zrozumiała. Jednak J. Funck, biorąc zapewne pod uwagę kłopoty księcia Albrechta ze znaczną grupą ortodoksyjnych luteran, zapytał J. Černýego, jak ma rozumieć treść tego kazania. Nie sądzi, aby bracia uważali, że władza świecka ma chronić bezbożnych klechów („gotlosen pfaffen”). Odpowiedź J. Černýego była uspokajająca. Mówił, że jeśli duchowni głoszą czyste Słowo Boże, to nie ma powodów, aby władza świecka wkraczała w ich działalność. W wypadku naruszeń winni być najpierw upominani przez swoich duchowych zwierzchników. Jeśli są notorycznie niepoprawni, to władza świecka ma prawo ich karać, gdyż nie są sługami Słowa Bożego, lecz złośliwymi łajdakami („nicht gottes diener, sondern bose buben”). Dodał, że ma nadzieję, iż Bóg będzie prowadził księcia jak dotychczas, aby nic przeciw Chrystusowi (w jego kraju) się nie działo.

Wreszcie 2 IX 1555 r. odwiedzili J. Funcka w jego gospodzie J. Černý i J. Lorenc z prośbą o przekazanie księciu Albrechtowi ich uwag. W gospodzie byli akurat W. Křinecký i kilku innych „panów”. Po pierwsze, prosili, aby J. Funck i W. Křinecký zapewnili księcia o ich wiernych służbach. Po drugie, upraszali, aby wyrazili księciu wdzięczność - w ich imieniu - za opiekę nad ich współwyznawcami wygnanymi z Czech i Moraw. Po trzecie, obiecali natychmiast po powrocie do domu przesłać księciu ich księgi religijne ${ }^{48}$. Po czwarte, w sprawie A. Bodensteina nie

${ }^{47}$ O Interim z roku 1548 zob. J. MAŁŁEK, Reformacja i protestantyzm w Polsce i Prusach, s. 42-50.

${ }^{48} \mathrm{O}$ nich: QGBB, s. $112 \mathrm{n}$. 
będą zwlekać i natychmiast po odbyciu rozmowy powiadomią księcia o jej rezultacie. Po piąte, proszą księcia, aby wspierał w Polsce uchwały przyjęte na synodzie w Koźminku.

Na koniec Jan Tomicki ${ }^{49}$, kasztelan rogoziński, oraz Jakub Ostroróg ${ }^{50}$ prosili, aby J. Funck zapewnił księcia o ich wiernych służbach. Gdyby była taka potrzeba, są gotowi służyć księciu zarówno majątkiem, jak i życiem. Mogą przybyć (na pomoc) $\mathrm{w}$ razie potrzeby w tysiąc, a nawet 2 lub 3 tysiące koni. J. Funck podziękował za tę deklarację i wyraził nadzieję, że nie będzie to konieczne. Oświadczenie J. Tomickiego i J. Ostroroga świadczy o tym, że mieli wiedzę o niepokojach religijnych w Księstwie Pruskim i mieli pełne zaufanie do polityki religijnej księcia Albrechta. Obydwaj usilnie prosili, aby J. Funck poinformował księcia o jedności chrześcijańskiej, jaka miała miejsce na synodzie w Koźminku. O to samo apelowali też pozostali przedstawiciele rycerstwa tak z Małopolski, jak i Wielkopolski: Stanisław Lasocki $^{51}$, Hieronim Filipkowski ${ }^{52}$, Andrzej Trzecieski ${ }^{53}$ oraz Stanisław Lutomirski ${ }^{54}$ - pastor z Konina. Ten ostatni anonsował swoją wizytę u księcia Albrechta w Królewcu w niedługim czasie. Nazwiska polskich rozmówców zapamiętał W. Křinický i podał je J. Funckowi.

Jego relacja z synodu w Koźminku w roku 1555 nie jest szczegółowym protokołem obrad synodalnych, bo te mamy opublikowane w tomie 1 . Akt synodów róż-

${ }^{49}$ Jan Tomicki h. Łodzia (1519/1520-1575), bratanek biskupa krakowskiego Piotra Tomickiego, kasztelan rogoziński, od 1564 r. kasztelan gnieźnieński. W latach 1554-1559 korespondował z księciem Albrechtem. O swoich rozmowach z J. Funckiem i Skřineckým w Koźminku J. Tomicki informował księcia Albrechta w liście datowanym 6 IX 1555 r. z Lisewa. Zob. Roman ŻELewski, Tomicki Jan, [in:] Wielkopolski słownik biograficzny, Warszawa-Poznań 1981, s. 767; ASRP, t. 1, s. 362 (indeks); Elementa ad Fontium Editiones, edidit Carolina LanckorońsKa, t. 50, Romae 1980, s. 193 (indeks); t. 40, Romae 1976, s. 50, nr 1496.

${ }^{50}$ Jakub Ostroróg h. Nałęcz (1516-1568), poseł z województwa poznańskiego, właściciel Koźminka, od roku 1566 starosta generalny Wielkopolski, członek Jednoty Braci Czeskich. Zob. Maria Barbara Topolska, Ostroróg Jakub, [in:] PSB, t. 24, Wrocław-Warszawa-Kraków-Gdańsk 1979, s. $500-502$.

${ }^{51}$ Stanisław Lasocki (około 1521-1563), podkomorzy łęczycki, działacz reformacyjny. Zagorzały obrońca unii zawartej w Koźminku. W roku 1556 został diakonem świeckim w kościele małopolskim. Zob. Halina KowALsKa, Lasocki Stanisław, [in:] PSB, t. 16, Wrocław-Warszawa-Kraków-Gdańsk 1971, s. 548-549.

${ }^{52}$ Hieronim Filipkowski h. Pobóg (zmarły przed 1574 r.), poseł sejmowy, wybitny zwolennik reformacji, potem związał się z arianizmem. Zob. Stanisław Szczotka, Filipkowski Hieronim, [in:] PSB, t. 6, Kraków 1948, s. 457-460.

${ }^{53}$ Andrzej Trzecieski h. Strzemię (urodzony około 1530 r., zmarły w 1583 r.), działacz reformacyjny. Studiował w Wittenberdze. Zob. ASRP, t. 1, s. 363 (indeks); Wielka encyklopedia powszechna $P W N$, t. 6, Warszawa 1998, s. 473.

${ }^{54}$ Stanisław Lutomirski (około 1520-1575), ksiądz, pisarz reformacyjny. Główny redaktor Konfesji polskich protestantów przedłożonej Zygmuntowi Augustowi 3 V 1555 r. na sejmie w Piotrkowie. W latach 1554-1559 korespondował z księciem Albrechtem. Zob. Halina KowalsKa, Lutomirski Stanisław, [in:] PSB, t. 18, Wrocław-Warszawa-Kraków-Gdańsk 1973, s. 144-146; Elementa ad Fontium Editiones, t. 50, s. 185 (indeks listów). 
nowierczych. Jest natomiast świadectwem rozmów po części zakulisowych między protestantami pruskimi a polskimi i czeskimi.

prof. dr hab. Janusz Małtek

Instytut Historii i Archiwistyki

Uniwersytet Mikołaja Kopernika w Toruniu

e-mail:jm@umk.pl

\author{
DER BERICHT DES JOHANN FUNCK VON DER SYNODE IN KOZMINEK \\ IM JAHR 1555 (BEMERKUNGEN ZU DEN KONTAKTEN DER PROTESTANTEN \\ AUS DEM HERZOGLICHEN PREUSSEN, POLEN UND BÖHMEN)
}

Zusammenfassung

Schlüsselwörter: Herzog Albrecht von Hohenzollern, Herzogliches Preußen, Böhmische Brüder, Protestantismus, Union von Kozminek, protestantische Synoden.

Der Artikel besteht aus drei Teilen. Im ersten geht es um den Forschungsstand zur Synode in Kozminek im Jahr 1555, in deren Verlauf eine Bekenntnisunion zwischen den polnischen Protestanten und den Böhmischen Brüdern abgeschlossen wurde. Der zweite Teil nennt die Gründe dafür, dass Johann Funck, der Hofprediger Herzog Albrechts von Preußen, zu dieser Synode entsandt wurde. Herzog Albrecht wollte Näheres über die konfessionelle Situation in Polen erfahren, nachdem die Szlachta beim Sejm in Petrikau im Mai 1555 die Annahme der Augsburgischen Konfession von 1530 und die Einberufung einer Nationalsynode gefordert hatte. Genauso interessierte er sich für die Haltung der Böhmischen Brüder, von denen eine Gruppe im Herzoglichen Preußen wohnte, gegenüber den theologischen Streitigkeiten in seinem Herzogtum, die sich an der Lehre Andreas Osianders entzündet hatten, die er unterstützte. Der dritte Teil der Artikels bringt einen Bericht von den Gesprächen Johann Funcks mit dem Führer der Böhmischen Brüder, Jan Černy, und mit den polnischen Protestanten. Die Ansichten von Jan Černy zerstreuten die Befürchtungen Funcks, dass ein Gegner der Lehre Osianders, der Pastor Anton Bodenstein aus Osterode, Mitglied der Kirche der Böhmischen Brüder sei. Interessant ist die Erklärung des protestantischen Adels bei der Synode, er sei bereit den Herzog mit Waffengewalt zu unterstützen, wenn eine solche Notwendigkeit entstehe. 


\section{AN ACCOUNT BY JOHANNES FUNCK FROM THE SYNOD OF KOZMINEK IN 1555 (THE CONTRIBUTION TO THE CONTACTS OF PROTESTANTS FROM THE DUCHY OF PRUSSIA, POLAND AND BOHEMIA)}

\section{Summary}

Key words: Prince Albrecht Hohenzollern, the Duchy of Prussia, the Bohemian Brethren, Protestantism, the union of Kozminek, Protestant synods

The article consists of three parts. The first part addresses the condition of research on the synod of Kozminek of 1555, during which the religious union between Polish protestants and the Bohemian Brethren was concluded. In the second part of the article the author presents the reasons for Johannes Funck (a preacher of Albrecht of Prussia) being sent to the synod. Prince Albrecht wanted to become familiar with the religious situation in Poland in connection with the stance of the Polish noblemen at the seym in Piotrków in May 1555 insisting on the approval of the Augsburg Confession of 1530 and the convening of the national synod. He was also interested in the attitude of the Bohemian Brethren towards the theological disagreement in his duchy connected with the preachings of Andreas Osiander, which he supported. The third part of the article constitutes an account of the talks of Johannes Funck with the leader of the Bohemian Brethren - Jan Černy and the Polish protestants. The beliefs of Jan Černy dispelled the fears of J. Funck that the opponent of A. Osiandra's preachings - Antoni Bodestein - a pastor from Ostróda was a member of the Church of the Bohemian Brethren. It is interesting that the Protestant noblemen gathered at the synod declared that they were prepared to offer military support to the prince if need be. 